from $0.20 \mathrm{mmol} / 1$ at baseline to $0.55 \mathrm{mmol} / 1$ at three months and then dropped to 0.4 $\mathrm{mmol} / \mathrm{l}$ at seven months. The changes in markers of bone turnover are as shown in the table with a more than twofold rise in serum osteocalcin and the carboxyterminal propeptide of type 1 collagen (PICP) as markers of bone formation and a 1.5 fold rise in the leve of the carboxyterminal cross linked telopeptide of type 1 collagen (ICTP) and urinary hydroxyproline/creatinine ratio $(\mathrm{OHP} / \mathrm{Cr}$ ) as markers of bone resorption. These reflect the general increase in bone turnover induced by growth hormone treatment.

Growth hormone in hypophosphataemic rickets

\begin{tabular}{lllll}
\hline $\begin{array}{l}\text { Months of } \\
\text { treatment }\end{array}$ & $\begin{array}{l}\text { Osteocalcin } \\
(\mathrm{ng} / \mathrm{ml})\end{array}$ & $\begin{array}{l}\mathrm{PICP} \\
(\mathrm{ng} / \mathrm{ml})\end{array}$ & $\begin{array}{l}\text { ICTP } \\
(\mathrm{ng} / \mathrm{ml})\end{array}$ & $\begin{array}{l}\text { OHP/Cr } \\
(\mu \mathrm{mol}) \\
\mathrm{mmol})\end{array}$ \\
\hline 0 & 30 & 241 & $22 \cdot 0$ & 178 \\
3 & 78 & 542 & $30 \cdot 2$ & 261 \\
7 & 85 & 598 & $30 \cdot 3$ & 179 \\
\hline
\end{tabular}

These initial results are encouraging and suggest a potential therapeutic role for growth hormone in this condition, although it remains to be seen whether the effect on the tubular reabsorption of phosphate can be maintained long term.

N J SHAW

Department of End Birmingham Children's Hospital, Ladywood Middleway, Ladywood, Birmingham B16 8ET

C SHARP M DAVIE

Charles Salt Research Institute, Robert fones and Agnes Hunt Hospital, Oswestry, Shropshire SY10 $7 A G$

\section{Treatment of fragile $\mathrm{X}$ syndrome}

EDITOR,-In Slaney et al's otherwise impressive and important paper on DNA testing for fragile $\mathrm{X}$ syndrome in schools for learning difficulties, ${ }^{1}$ the authors state that 'treatment is not possible at the present time'. Although a cure is not possible at the present time there is good evidence for benefits of medical interventions (for example, the use of stimulants or folic acid for the frequently associated attentional deficits and hyperactivity ${ }^{2}{ }^{3}$ ), and specific educational approaches focusing on the profile of cognitive, social, and behavioural deficits frequently witnessed in young people with fragile $\mathrm{X}$ syndrome. ${ }^{45}$ In addition, behavioural psychotherapy techniques can be invaluable in tackling such maladaptive behaviours as hyperactivity, self injury, and obsessionality. Families are entitled to know that while the condition cannot be cured there is much that can be done to maximise affected individuals' potential and to minimise their handicaps. JEREMY TURK
Department of Mental Health Services,
St George's Hospital Medical School, St George's Hospital Medical School, fenner Wing, Cranmer Terrace Tooting, London SW17 ORE

1 Slaney SF, Wilkie AOM, Hirst MC, et al. DNA testing for fragile $\mathrm{X}$ syndrome in schools for learning difficulties. Arch Dis Child 1995; 72: 33-7.

2 Hagerman J, Murphy MA, Wittenberger MD. A controlled trial of stimulant medication in children with the fragile $\mathrm{X}$ syndrome. $A m \mathcal{F} M e d$ Genet 1988; 30: 377-92.

3 Turk J. Fragile X syndrome and folic acid. In: Hagerman RJ, McKenzie P, eds. International fragile $X$ conference proceedings. Dillon,
Colorado: Spectra Publishing, 1992: 195-200. Gibb C, Holliday J. Fragile-X syndrome and education. British fournal of Special Education 1992; 19: 65-7.

5 Turk J, Hagerman RJ, Barnicoat A, McEvoy J. The fragile $\mathrm{X}$ syndrome. In: Bouras $\mathrm{N}$, ed. Mental health and mental retardation - recent advances and practices. Cambridge: Cambridge University Press, 1994: 135-53.

\section{Perianal infection with $\beta$ haemolytic streptococcus}

EDITOR,-I am writing in reference to the article by Wright and Butt on perianal infection with $\beta$ haemolytic streptococcus. ${ }^{1}$ In the discussion of the article the author notes, 'the disorder has been mistaken for child abuse leading to unnecessary social investigation and family distress'. It needs to be stressed that genital trauma and anal trauma can predispose to infection and that I have seen one case where a child sustained anal sexual trauma and subsequently developed perianal $\beta$ haemolytic streptococcus infection. The $\beta$ haemolytic streptococcus would find a traumatised anus an easier target than an untraumatised anus.

In my opinion, any child who presents with a perianal infection has to have sexual abuse considered as a possible diagnosis by the examining doctor.

$$
\begin{array}{r}
\text { PETER M WINTERTON } \\
\text { Child Sex Abuse Unit, } \\
\text { Princess Margaret Hospital for Children, } \\
\text { Perth, } \\
\text { Western Australia } 6001
\end{array}
$$

1 Wright JE, Butt HL. Perianal infection with $\beta$ haemolytic streptococcus. Arch Dis Child 1994; 70: 145-6. 